\title{
Study on the buffer zone of a Cultural Heritage site in an urban area: the case of Shenyang Imperial Palace in China
}

\author{
Q. Li, F. Yuichi \& M. Morris \\ Graduate School of Engineering, \\ Division of Architecture and Urban Science, Chiba University, Japan
}

\begin{abstract}
This paper discusses the problem of how to manage urban development around a World Heritage site by focusing on the case of Shenyang Imperial Palace, China. The conclusion shows that buffer zone regulation and maintenance is important, not only to highlight the central monument, but also to conserve the historic urban landscape and to link contemporary buildings to the urban historical context. More cooperation from local residents is needed, particularly to extract genius loci or the spirit of the place from the cultural properties. It has become normal for skyscrapers to be built or to exist in the area around designated historic sites. In order to preserve the integrity of the historic landscape, it is necessary to promote an integrated and harmonious relationship between traditional conservation and new architectural and urban developments. Moreover, methods of controlling high-rise building beyond the buffer zone also becomes a serious topic in the context of historic urban landscape. As determined by the regulation for "the protection of the Imperial city in Shenyang" the buffer zone is divided into the Key Protection Area and Ordinary Protection Zone, and the height of buildings is limited to 9-30 meters according to their distance from the core. The government has made great efforts to preserve the core so as to apply for World Heritage designation before July, 2004. However, it is a great pity that old and traditional buildings in the buffer zone have been destroyed and a 43-storey high-rise building was built close to the buffer zone in 2006.

Keywords: Shenyang Imperial Palace, World Heritage, buffer zone, HUL, Vienna Memorandum, genius loci.
\end{abstract}




\section{Introduction}

\subsection{Background, purpose and method}

At present, it is a normal phenomenon for skyscrapers to be built or to be in the course of construction in the area around a designated historic site. For example, the tall structure of the Pelli Tower in Seville, the office and apartment blocks surrounding the Hiroshima Peace Memorial in Japan and the building rising near the tower of London in the UK and so on. The control of high-rise building near World Heritage sites becomes a serious problem in the context of historic urban landscape. Not only is the regulation of buffer zones of World Heritage sites necessary, but the method of determining them (including their range and the content of regulations and method of maintenance) and the buffer zone outerregion controls need to be well analyzed.

In this paper, the problem of how to manage urban development around a World Heritage site is considered by taking the case of Shenyang Imperial Palace, China. With the implementation of economic reforms in China and the openingup policy adopted since 1980, all Chinese cities have changed enormously, and this includes Shenyang, the biggest city in northeast China. We will discuss how the situation developed in the buffer zone of Shenyang Imperial Palace, during the nine years after it was added to the World Heritage list in 2004. In this way, the problems of the buffer zone of Shenyang Imperial Palace will be highlighted clearly and proposals for solving these problems will be also discussed in some detail.

Three professionals closely involved in the World Heritage Application were interviewed (Professor Chen Bochao of Shenyang Architecture University; Mr. Li Shengneng, vice-president of Shenyang Imperial Palace, and Mr. Tong Yue, researcher of Shenyang Imperial Palace) and so were residents of the area near Shenyang Imperial Palace.

\subsection{Shenyang Imperial Palace and the Square City}

Shenyang Imperial Palace was built as an imperial residence in the early years of the Qing Dynasty. It is a UNESCO World Heritage site. It is one of only two imperial palaces (the other is the Forbidden City in Beijing) to survive in China. It was established between 1624 and 1636 when the Qing regime was establishing itself, and is famous all over the world for its unique "Manchu" architectural features. The two imperial palaces constituted one World Heritage designation, under the title "Imperial Palaces of the Ming and Qing Dynasties". Shenyang Imperial Palace witnessed the glory of the reigns of Nu'erhachi and Huangtaiji [1] and was showered with honours and privileges during imperial visits to the east, throughout the Qing Period. It suffered during unrest in the first half of the $20^{\text {th }}$ century but survived intact through the period that saw the establishment of modern China. It is a cultural property of truly immeasurable significance.

Shenyang Imperial Palace, with its 400-year history, has been registered as a World Heritage site since July 1st, 2004. It is surrounded by four roads and the 
total length of the east-west road and the north-south road is $1.3 \mathrm{~km}$ in each case. For this reason it is called "the Square City". In the area of "the square city", there are three kinds of buildings: contemporary buildings, Chinese traditional buildings and western-style buildings [2].

\section{Buffer zone}

\subsection{The definition of the buffer zone}

As stated by the Operational Guidelines for the Implementation of the World Heritage Convention in 1980, a buffer zone can be defined as an area surrounding the property, which has an essential influence on the physical state of the property and or on the way in which the property is perceived.

Consistent with the Operational Guidelines for the Implementation of the World Heritage Convention in 1988, a buffer zone can be defined as an area surrounding the property, which has restrictions placed on its use to give an added layer of protection to the designated site.

\subsection{The context of the buffer zone}

In accordance with the Operational Guidelines for the Implementation of the World Heritage Convention in 2005, 2008 and 2011 [3], for the purpose of effective protection of the nominated property, a buffer zone is an area surrounding the nominated property that has complementary legal and/or customary restrictions placed on its use and development to give an added layer of protection to the property. This should include the immediate setting of the nominated property, important views and other areas or attributes that are functionally important as a support to the property and its protection. The area constituting the buffer zone should be determined in each case through appropriate mechanisms. Details on the size, characteristics and authorized uses of a buffer zone, as well as a map indicating the precise boundaries of the property and its buffer zone, should be provided in the nomination.

\subsection{The process of defining the buffer zone of Shenyang Imperial City}

Shenyang was designated as a Historic and Cultural City under Chinese legislation in 1986. The Square City was defined as an important protected area in the Shenyang Master-plan of 1996. Moreover, in 1998, a "Detailed Plan for Controlling the Square City" was also issued [4]. It puts special emphasis on the Square City as one of the important components of the Historical and Cultural City of Shenyang. The more detailed regulations in "The Protection Plan for the Imperial Palace of the Qing Dynasty in Shenyang" [5] were promulgated on the basis of the above plans in 2003. Furthermore, "The protection plan for Shenyang Imperial City of the Qing dynasty" was published in the course of applying for World Heritage nomination by the Shenyang Culture Bureau in May, 2003. It clearly defined the range of the area to be protected, and the measures to be taken, etc. 


\subsection{The outline of the buffer zone and control zone}

\subsubsection{Scope of the protection and control zone}

The Shenyang Imperial Palace of the Qing Dynasty is located at the urban center of Shenyang, its precise position being between $41^{\circ} 47^{\prime} 39^{\prime \prime}-41^{\circ} 47^{\prime} 49^{\prime \prime}$ north and $123^{\circ} 26^{\prime} 49^{\prime \prime}-123^{\circ} 27^{\prime} 03^{\prime \prime}$ east. In line with the Law of the People's Republic of China on the Protection of Cultural Relics and related regulations, the protection zone and construction control zone are both defined in the case of Shenyang Imperial Palace. The protection zone is divided into the Key Protection Area and Ordinary Protection Zone (Figure 1).

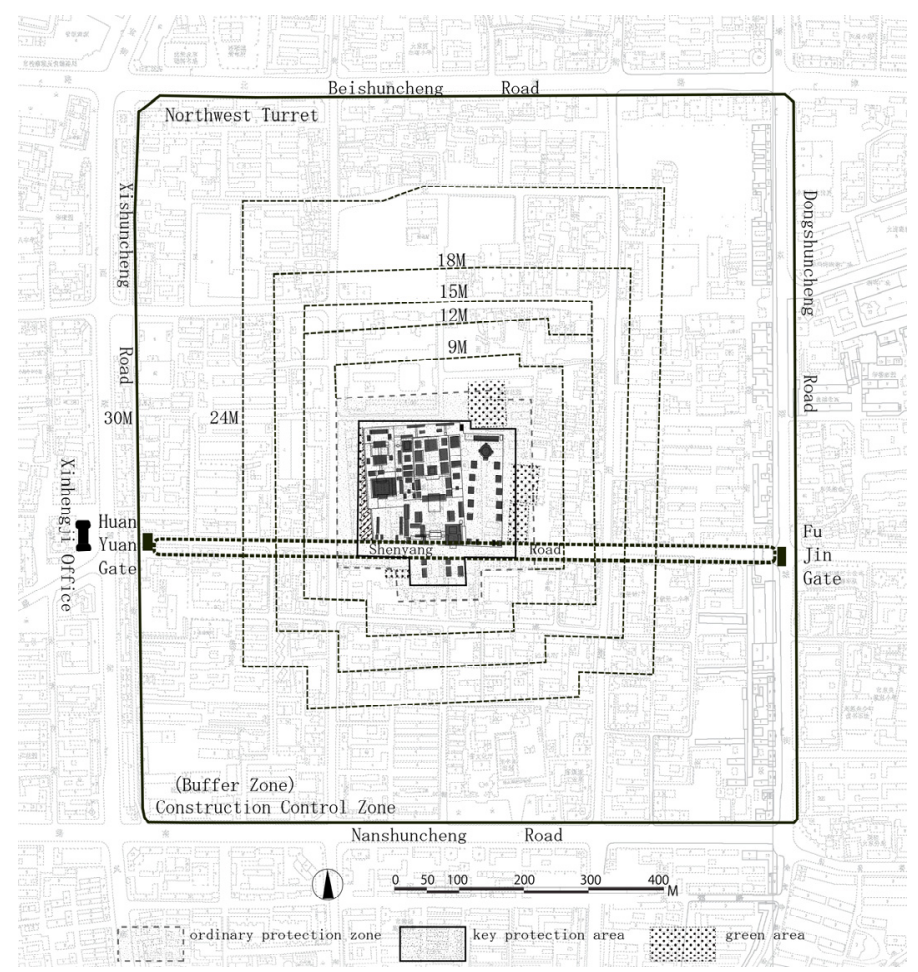

Figure 1: The present situation on the buffer zone.

The Key Protection Area: the area within the red walls of the northern compound and 15 meters beyond the walls in the north and east, extending westward to the eastern side of Zhengyang Street, and southward to the southern side of Shenyang Road. For the southern compound, it is the area within the encircling wall and 9 meters beyond the walls in the east, south and west.

The Ordinary Protection Zone: For the northern compound, this extends 45 meters eastward, northward and westward and 30 meters southward from the 
boundary of the Key Protection Area. For the southern compound, it extends 21 meters eastward, southward and westward from the boundaries of the Key Protection Area.

The Construction control zone: this extends from the boundary of the Protection Zone to the west side of Dongshuncheng Street in the east, to the north side of Nanshuncheng Road in the south, to the east side of Xishuncheng Street in the west, and to the south of Beishuncheng Road in the north (this coincides with the boundaries of the Square City). The height limits for buildings within the construction control zone of the Shenyang Imperial Palace are specified as $9 \mathrm{~m}$, $12 \mathrm{~m}, 15 \mathrm{~m}, 18 \mathrm{~m}, 24 \mathrm{~m}$ and $30 \mathrm{~m}$, respectively, according to their distance from the center (the greater the distance is, the higher the building is permitted to be).

In the "The Protection Plan on Shenyang Imperial City of the Qing dynasty", not only the height limitation, but also the volume, the color and the spatial dimensions of buildings were regulated in order to be in harmony with, and an appropriate complementary landscape for Shenyang Imperial City. Although it is regrettable that there was no concrete example given to show how the criteria might be applied, in the case of a building being planned to be constructed in the Square City. It is, however, necessary to get permission from a department of the City-planning Bureau in Shenyang and the administrative section of the National cultural property Bureau. However, after the inscription of the World Heritage, instead of construction of new buildings, a policy of reducing the number of buildings has been implemented and more and more buildings have been demolished.

\section{The actual state of the buffer zone}

\subsection{Current circumstances}

Following designation of the palace as a the World Heritage site, some measures have been taken to deal with the buffer zone in terms of the rules laid down at that time.

For the buildings above the height limitation, a "subtraction principle" was applied and the part exceeding the height limitation was removed. For instance, in the middle of $9 \mathrm{~m}$-height limitation zone, the top two storeys the Shenjing Garden (an apartment block) were pulled down.

In order to make a green belt and leisure square, six buildings of Yuyuanxindu (an apartment block) and the office of the Geology Bureau of Northeast China including its dormitory and the Hongqiang Market and other outbuildings were also demolished.

Historic buildings were conserved and maintained; however, there uses were changed, often to functions that reflected their original uses in some way. For example, the old Bian Ye Bank was converted to Shenyang Finance Museum. And the old Japan South Manchurian Railway Corporation building was converted into the Shenyang Children's Library.

In the neighboring area, the color of existing buildings and additions were repainted to match the Shenyang Imperial City. As a result, Shenyang Road has 
been transformed into a remarkably colorful length of streetscape. New buildings that obey the strict height restrictions have been built with the permission of Shenyang construction Bureau since the World Heritage designation of 2004.

\subsection{Remodeling Tongtian Street}

In order to link Shenyang Imperial City and the early $20^{\text {th }}$ century Zhang Mansion (the official residence of the warlord, General Zhang Xueliang of the post-Imperial Chinese Republican era), the proposal of recreating the Tongtian Street was made by Tsinghua University and Shanghai Tongji University. On the other hand, there was opposition to this from other quarters on the grounds that the Tongtian Street was one of the Ming dynasty streets and was therefore not appropriate in conjunction with Shenyang Imperial Palace, which was built under the Qing dynasty (Figure 2).
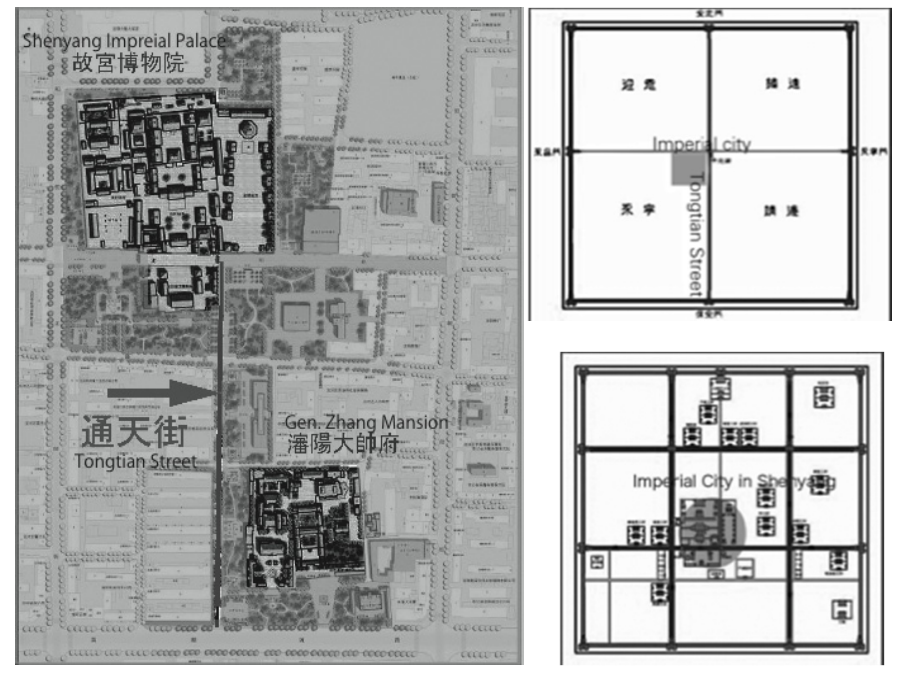

Figure 2: Romodeling of the Tongtian Street (upper right: the Square City, which existed during the Ming period; lower right: the Square City in the Qing period).

\section{Problems outside the buffer zone of Shenyang Imperial Palace}

In the middle of the buffer zone, changes were carried out steadily. However, with the rapid development of the economy in Shenyang, a CBD (central business district) was established in the Shenhe district (in which Shenyang Imperial Palace is located) and made it an important economic area. This has led to the erection of contemporary buildings outside the buffer zone which have had a detrimental impact on Shenyang Imperial City itself. The most notable example is the New 
Hengji building, which is a 43-storey tower (including 3 storeys underground), 185.8-meter high, located in front of Shenyang Road, one of the main access routes to Shenyang Imperial Palace. The local people in Shenyang have been heavily critical of this building, because it was built with solely commercial concerns in mind, as a good location for office space, and nothing was done to prevent its construction although it is clearly detrimental to the beauty of the historic urban landscape (HUL) surrounding Shenyang Imperial Palace (Figure 3).

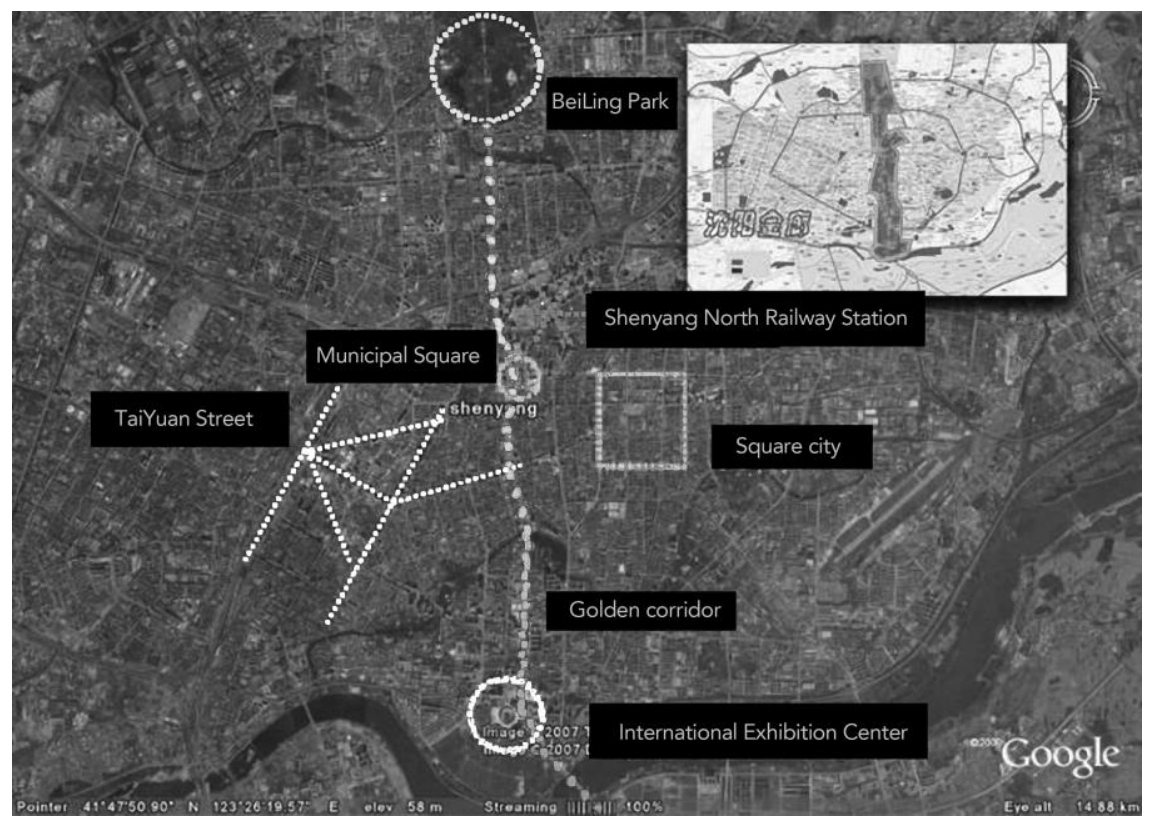

Figure 3: Shenyang's CBD (Central Building District).

\section{The present state of international discussion about buffer zones and historic urban landscape}

With around half of the world's population living in urban areas today, and bearing in mind the projected growth of urbanization over the coming decade, the pressure on areas around World Heritage sites and their historic urban landscape will continue to mount, making urban and landscape conservation one of the most volatile and daunting tasks of our time. Debates at World Heritage Committee sessions in recent years concerned with high-rise construction and contemporary architectural interventions in the areas around World Heritage sites have increased dramatically. Meetings to refine ideas set out in the Vienna Memorandum [6] (the result of an international conference on the subject of "World Heritage and Contemporary Architecture") have been held and debates on Historic Urban Landscape (HUL) have taken place, recalling regional consultations on the subject of HUL, at meetings held in Jerusalem (June 2006), Saint Petersburg, Russian 
Federation (January 2007), Olinda, Brazil (November 2007), Zanzibar and Rio de Janeiro (2009). Especially, new recommendations on HUL [7] have been negotiated and were approved in September, 2011. Not only does HUL address the problem of high-rise building intervention but it also includes tangible landscape and intangible cultural property as new points to be considered in the context of research in the area of international heritage conservation in the years ahead.

\section{Analysis}

"Taking into account the emotional connection between human beings and their environment, and their sense of place, it is fundamental to guarantee an urban environmental quality of living to contribute to the economic success of a city and to its social and cultural vitality" (Vienna Memorandum No. 16).

In the buffer zone of Shenyang Imperial Palace, it is unacceptable to demolish too many buildings without regard to the interests of ordinary people, especially when they include traditional houses. In fact, in areas where height limitations are in force, some measures have been taken to regulate building height. So it is not necessary to destroy buildings that do not exceed the height limitation. Furthermore, although pursuit of economic profit is understandable, high-rise buildings (such as the new Hengji International Building) which have a detrimental impact on the beauty of the buffer zone, even if located outside it, should not be permitted. Such buildings could be built further away from Shenyang Imperial Palace, but should not be visible from the main access to the Imperial Palace. In this way, the modern economic needs of Shenyang could be met.

The Jerusalem meeting concluded that the Vienna Memorandum was a useful document for further debate but that in particular more emphasis was needed on natural elements, intangible heritage, and cultural diversity, to enhance the spirit of place (genius loci). Needs could be more effectively defined by cultural mapping, with protection of the wider setting - visual, cultural and natural - as the principal aim.

But the regulation of the buffer zone of Shenyang Imperial Palace placed too much emphasis on the issue of height limitation and ignored the need for understanding of the spirit of place. Now, In the Square City, there are no traditional houses matching Shenyang Imperial Palace at all, while concrete buildings abound. Therefore, Shenyang's Square City has lost its historic identity.

"The central challenge of contemporary architecture in the historic urban landscape is to respond to development dynamics in order to facilitate socioeconomic changes and growth on the one hand, while simultaneously respecting the inherited townscape and its landscape setting on the other. Living historic cities, especially World Heritage cities, require a policy of city planning and management that takes conservation as one key point for conservation. In this process, the historic city's authenticity and integrity, which are determined by various factors, must not be compromised" (Vienna Memorandum No. 14). 
In the case of the buffer zone of Shenyang Imperial Palace, It was not reasonable to recreate Tongtian Street. Firstly, Shenyang Imperial Palace was built under the Qing dynasty, whereas Tongtian Street was built under the Ming dynasty. They belong to different periods and are therefore in different in style and meaning. Secondly, according to Qing dynasty traditional customs, it was not permitted to enter Shenyang Imperial Palace directly on its central axis. But now, because of Tongtian Street straight such axial entry is possible. Actually, the construction of Tongtian Street does not reflect the World Heritage's concept of authenticity but a response the perceived possibilities of tourism (Figure 2).

\section{Conclusion}

In the words of Mr. R. Van Oers [8] "Preservation does not mean an end to growth and development. It requires, however, designing respectful solutions according to the character and values of the historic environment". A world Heritage site is not just any old site and it requires special treatment. Therefore, high-rise construction should be positioned sufficiently distant from historic areas so as not to disturb sensitive balances in the environment, or obstruct views of or from historic landmarks and landscapes. Furthermore, the individual countries are invited to use the new concept of HUL and make it operational within their own policies and strategies for conservation management. In addition, some of those interviewed were eager for UNESCO or ICOMOS to monitor Shenyang on a regular basis. It would be useful to establish a monitoring and reporting feedback mechanism that could really be implemented.

\section{References}

[1] Yue, Tong, Shenyang Imperial Palace, Shenyang Ethnic Publishing Firm: Shenyang, pp. 11-15, 2003.

[2] Bochao Chen, Shenyang city architecture illustrator, Mechanical and Industry Publishing Firm: Peking, pp. 10-22, 2010.

[3] United Nations Educational, Scientific and Cultural Organization. Operational Guidelines for the Implementation of the World Heritage Convention, July 2012, http://whc.unesco.org/archive/opguide12-en.pdf

[4] Detail Plan on Controlling the Square City, Shenyang city planning and Design Institute: Shenyang, 1998.

[5] The Protection Plan for the Imperial Palace of the Qing Dynasty, Shenyang Municipal Department of Culture: Shenyang, 2003.

[6] Vienna Memorandum, http://whc.unesco.org/archive/2005/whc05-15gainf7e.pdf

[7] United Nations Educational, Scientific and Cultural Organization. Recommendation on the Historic Urban Landscape, November 10,2011 http://whc.unesco.org/en/activities/638.pdf

[8] Van Oers R. Towards new international guidelines for the conservation of urban, 2007,

http://www.ceci-br.org/novo/revista/docs2008/CT-2008-113.pdf 